\title{
Evaluation of Genotoxicity of CSE1034 by Ames and In vitro Chromosomal Aberration Tests
}

\author{
Manu Chaudhary and Anurag Payasi* \\ Venus Medicine Research Centre, Hill Top Industrial Estate, Bhatoli Kalan, Baddi, H.P. - 173205, India
}

*For correspondence: Email: ccmb@venusremedies.com; Tel: +91-1795-302005; Fax: +91-1795-302133

Received: 1 February 2013

Revised accepted: 3 February 2014

\begin{abstract}
Purpose: To evaluate the genotoxicity of CSE1034, a novel antibiotic adjuvant entity, using bacterial reverse mutation assay (Ames test) and in vitro chromosomal aberration test.

Methods: Reverse mutation test was carried out using four strains of Salmonella typhimurium (TA 98, TA100, TA1535 and TA1537) and one strain of E. coli [WP2 (uvrA)], while chromosomal aberration test was done with cultured Chinese hamster lung (CHL) cells. Reverse mutation test was carried out in a dose range of 0.0015 to $0.16 \mu \mathrm{g} / \mathrm{plate}$ in triplicate with and without S9 activation.

Results: No significant increases in the number of revertants were observed at the dose levels where antibacterial effects were not noted. CSE1034 caused no increase in the number of chromosomal aberrants at dose levels of $0.34,0.69,1.37,2.75$ and $5.50 \mathrm{mg} / \mathrm{ml}$ in the absence and presence of metabolic activation.

Conclusion: Based on the above observations, it can be concluded that CSE1034 has no mutagenic activity.

Keywords: CSE1034, reverse mutation, antibiotic adjuvant entity, Chromosomal aberration, Mutagenic

Tropical Journal of Pharmaceutical Research is indexed by Science Citation Index (SciSearch), Scopus, International Pharmaceutical Abstract, Chemical Abstracts, Embase, Index Copernicus, EBSCO, African Index Medicus, JournalSeek, Journal Citation Reports/Science Edition, Directory of Open Access Journals (DOAJ), African Journal Online, Bioline International, Open-J-Gate and Pharmacy Abstracts
\end{abstract}

\section{INTRODUCTION}

The evaluation of a mutagenic substance is an important procedure in safety analysis. Drugs that induce mutations can potentially damage the germ lines leading to fertility problems and mutations in future generations. Gene mutations are widely studied in bacteria whereas chromosome damage in mammalian cells is typically measured by analyzing chromosome breaks or re-arrangements. In recent years, genotoxicity has become more and more important in the process of early screening for potential compound [1]. Ames test is a rapid, convenient and widely accepted test for identifying substances which can produce genetic damage that leads to gene mutation [2].
CSE1034 is a novel antibiotic adjuvant entity developed by Venus Medicine Research Centre Baddi, Himanchal Pradesh, India. It comprises a $\beta$-lactam moiety and a $\beta$-lactamase inhibitor along with a novel non-antibiotic adjuvant EDTA (ethylene-diamine tetra-acetic acid). Clinically, this antibiotic combination has been expected as a therapeutic agent for multi drug-resistant grampositive and gram-negative organisms. As part of safety test for CSE1034, its genotoxicity was investigated by Ames test using five tester strains: Salmonella typhimurium TA98, TA100, TA1535 and TA1537, and Escherichia coli WP2uvrA, and by an in vitro chromosomal aberration test using Chinese hamster lung fibroblast (CHL/IU) cells. The Salmonella and $E$. coli strains used in the test have different 
mutations in various genes in the histidine and tryptophan operon; each of these mutations is designed to be responsive to mutagens that act via different mechanisms. Additional mutations were engineered into these strains to make them more sensitive to a wide variety of substances [3].

\section{EXPERIMENTAL}

\section{Chemicals}

A novel antibiotic adjuvant entity (AAE), with ceftriaxone sodium plus sulbactam sodium in ratio of 2:1 plus $10 \mathrm{mM}$ EDTA disodium herein after referred to as CSE1034 was provided by Venus Remedies Limited, Baddi, H.P India. CSE1034 was dissolved in distilled water.

As positive control, sodium azide $\left(\mathrm{NaN}_{3}\right.$, Sigma), 9-aminoacridine, (9AA, Aldrich Chemical Company Limited), 2-nitrofluorene (NF, Aldrich Chemical Company Limited), benzo[a]pyrene (BP, Aldrich Chemical Company Limited), 2aminoanthracene (2-AAN, Aldrich Chemical Company Limited) and methyl methansulfonate (MMS, Aldrich Chemical Company Limited) were used. The 2-NF and 9-AA were prepared in sterile distilled water, whereas sodium azide $\left(\mathrm{NaN}_{3}\right), \mathrm{MMS}$ and BP were prepared in dimethyl sulfoxide (DMSO). Tryptophan and histidine were obtained from Thomas Baker (Chemicals) Limited, Mumbai, India. AroclorTM 1254-induced rat liver S9 (freeze-dried) was purchased from Trinova Biochem $\mathrm{GmBH}$ while nicotinamide adenine dinucleotide phosphate (NADPH) was obtained from Himedia (Mumbai, India).

\section{Ames test}

The test was conducted according to standard procedures following the guidelines of the Organization for Economic Co-operation and Development (OECD) [1]. Salmonella typhimurium strains TA100, TA98, TA1535, TA1537 and Escherichia coli strain WP2uvrA were obtained from Institute of Microbial Technology, Chandigarh, India. Frozen stock of bacterial cultures in a deep freezer $\left(-80^{\circ} \mathrm{C}\right)$ were inoculated into $3.0 \%$ nutrient broth (Himedia, Mumbai, India), and incubated with gentle shaking at $37 \pm 2^{\circ} \mathrm{C}$ for about $14-16 \mathrm{~h}$ until a cell density of about $10^{9}$ cell $/ \mathrm{ml}$ was obtained (determined by optical density). The characteristics of the tester strains, which were histidine- or tryptophan-dependent, ultravioletsensitive and had the presence of R-factor plasmid, were checked at the time of the test. Strain selection complied with published recommendations $[2,4]$.
The standard mix of S9/cofactor comprised of 2.1 $\mathrm{ml}(4 \%)$ of rat liver S9 (Aroclor-1254 induced), $1.05 \mathrm{ml}$ of salt solution (1.65 M KCL+0.4 M $\mathrm{MgCl} 2), 0.26 \mathrm{ml}$ of $1 \mathrm{M}$ glucose-6-phosphate, 2.1 $\mathrm{ml}$ of $0.1 \mathrm{M}$ NADP solution, $26.25 \mathrm{ml}$ of $0.2 \mathrm{M}$ sodium phosphate buffer, $\mathrm{pH} 7.4$ and $20.74 \mathrm{ml}$ sterile distilled water. The minimal glucose agar plate used for the mutagenicity assay consisting of $1.5 \%$ agar supplemented with $2.0 \%$ each of glucose and Vogel-Bonner medium $\mathrm{E}$. The top agar consisted of $0.6 \%$ agar and $0.5 \% \mathrm{NaCl}$, was supplemented right before use with $0.5 \mathrm{mM}$ solution of histidine (for Salmonella) and tryptophan (for E. coli).

Mutagenicity test was conducted using the plate incorporation method as described elsewhere $[5,6]$. The required quantity of CSE1034 (0.0015, $0.005,0.016,0.05$ and $0.16 \mu \mathrm{g} /$ plate) was added to the tube containing $0.5 \mathrm{ml}$ of $\mathrm{S} 9 /$ cofactor mix, $0.1 \mathrm{ml}$ of bacterial suspension (1-2 x 109 cells $/ \mathrm{ml}$ ) of each strain (TA1535, TA1537, TA98, TA100 and WP2 uvrA) and $2.0 \mathrm{ml}$ top agar. The tubes were vortexed, poured onto minimal glucose plates and evenly distributed. The agar was allowed to harden and the plates were inverted and incubated at $37^{\circ} \mathrm{C} \pm 2^{\circ} \mathrm{C}$ for $72 \pm 4 \mathrm{~h}$ and then scored. Positive and negative controls were similarly run.

\section{Counting procedure and data presentation}

The plates for all concentrations were counted by hand. Data are presented as the number of revertant colonies per plate. All data represent the mean \pm SD of three independent experiments.

\section{In vitro chromosomal aberration test}

The test was conducted according to the standard procedures following OECD guidelines [1]. In the chromosome aberration test, CHL/IU cells, a fibroblast cell line from the lung of a newborn Chinese hamster, were purchased from National Centre for Cell Science (NCCS), Pune, India. The cells were kept and passaged at our laboratory using the Eagle's minimum essential medium (MEM, Himedia, Mumbai, India) supplemented with $10 \%$ calf serum containing $0.12 \%$ sodium bicarbonate. The maximum dose of CSE1034 was selected from the doses at which $>50 \%$ cell growth inhibition was observed in a preliminary test. In the method without metabolic activation (direct method), the cells in $5 \mathrm{ml}$ of cell suspension (5000 cells $/ \mathrm{ml}$ ) were seeded in a $60 \mathrm{~mm}$ plastic petri plate and cultured for 24 or $48 \mathrm{~h}$. The solution of CSE1034 $(0.34,0.69,1.37,2.75$ and $5.50 \mathrm{mg} / \mathrm{ml})$ or mitomycin C (MMC) $(0.00005$ and $0.0001 \mathrm{mg} / \mathrm{ml})$ 
was added to the culture. The test compound was allowed to remain in the cultures for 24 or 48 hours. To arrest cell in metaphase $100 \mu \mathrm{l}$ of 10 $\mu \mathrm{g} / \mathrm{ml}$ colchicine (Sigma) was added to all cultures $2 \mathrm{~h}$ before harvest, and chromosome preparations were made as described earlier [7].

For metabolic activation, $0.5 \mathrm{ml}$ of $\mathrm{S9} \mathrm{mix}$ and various concentrations of CSE1034 (0.34, 0.69, $1.37,2.75$ and $5.50 \mathrm{mg} / \mathrm{ml}$ ) or $0.02 \mathrm{mg} / \mathrm{ml}$ of benzopyrine (BP) were added to 3-day old cultured cells. Cells were treated for 6 hours and washed with Dulbecco's phosphate buffer solution ( $\mathrm{pH} 7.4)$, and then re-cultured with a new culture medium for $18 \mathrm{hrs}$. The chromosomal preparations were made as described earlier [7]. The cells in 2 dishes per group treated with CSE1034, and 2 slides of chromosomal preparations were made from each dish. The frequency of the cells with structural and numeric chromosomal aberrations were scored for each dose. Types of structural chromosomal aberrations were classified into following groups: chromatid breaks (ctb), chromatid exchange (cte), chromosome breaks (csb), chromatid and chromosomal gap (ctg) and chromosome exchanges (cse) including dicentric and ring chromosomes total cells which have chromosomal aberrants including ctg (TAG), total cells which have chromosomal aberrant excluding ctg (TA). The final results of CSE1034 was judged as follows: negative (-) if the frequency of aberrant cells was $<5 \%$; inconclusive $( \pm)$ if $\geq 5 \%$ but $<10 \%$; and positive $(+)$ if $\geq 10 \%$.

\section{Dosage}

In the reverse mutation assay, a preliminary test was carried out using $S$. typhimurium strain TA100 with and without S9 mix to estimate the dosages of CSE1034 to be used. Since an antibacterial effect was observed at and more than $0.5 \mu \mathrm{g} / \mathrm{plate}, 0.16 \mu \mathrm{g} /$ plate was used as maximum concentration as well as four more diluted concentrations viz: $0.0015,0.005,0.016$ and $0.05 \mu \mathrm{g} /$ plate.

In the chromosome aberration test, a preliminary test to decide doses was carried out separately by the direct method and the metabolic activation method in consideration of difference of treatment time and effect of S9. Percent survival of cells treated with the test compound for 24 or $48 \mathrm{~h}$ in the direct method or for $6 \mathrm{~h}$ following recovery time of $18 \mathrm{~h}$ in the metabolic activation method are shown in Figure 1. The concentration showing $50 \%$ inhibition of cell growth was estimated to be around $4.0 \mathrm{mg} / \mathrm{ml}$ in the direct method, but could not be obtained in the metabolic activation method because the cell growth was inhibited by only $13 \%$ at the dose of $5.86 \mathrm{mg} / \mathrm{ml}$. Therefore, the test doses of CSE1034 in both methods were taken as 5.5 $\mathrm{mg} / \mathrm{ml}$ (the maximum dose), 2.75, 1.37, 0.69 and $0.34 \mathrm{mg} / \mathrm{ml}$ with a common ratio of 2 .

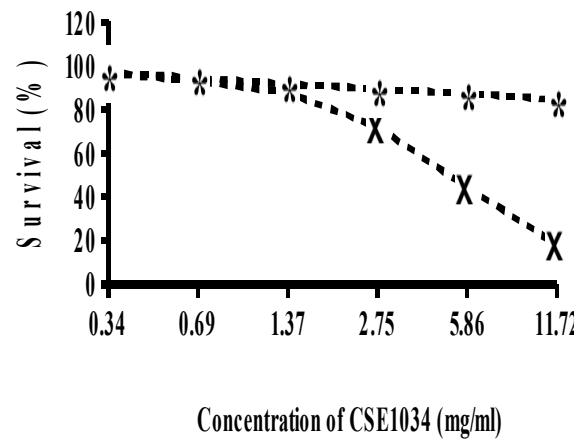

Figure 1: Survival curve of Chinese hamster lungtreated with CSE1034. Cells treated with CSE1034 for

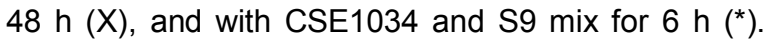
Survival was expressed as percentage of CSE1034 treated group to solvent control group

\section{Statistical analysis}

Data were analyzed using Graph Pad InStat-3 and expressed as mean \pm standard deviation (SD) of three independent experiments. The continuous variables were tested with one-way analysis of variance (ANOVA) and Dunnett's test values. $p<0.05$ was considered statistically significant.

\section{RESULTS}

\section{Reverse mutation}

The reverse mutation test results are summarized in Table 1. There was no significant difference in the number of revertant colonies of any of the strains in the test dose range relative to those of the corresponding solvent control with or without S9 mix ( $p>0.05)$. However, the number of revertant colonies in positive control increased remarkably with or without $\$ 9 \operatorname{mix}(p<0.001)$.

\section{In vitro chromosomal aberration}

The results of the chromosomal aberration test are shown in Table 2. The incidence of cells having aberrants (including gaps) in the chromosomal structure was $0-2 \%$ and $0-4 \%$ in solvent groups and CSE1034 treated groups, respectively, and the incidence of aberrant cells excluding gap was $0 \%$ and $0-2 \%$, respectively. 
Table 1: Mutagenicity data for CSE1034 with and without metabolic activation using Salmonella typhimurium and Escherichia coli strains

\begin{tabular}{|c|c|c|c|c|c|c|c|}
\hline \multirow{2}{*}{\multicolumn{2}{|c|}{ Compound }} & \multirow{3}{*}{$\begin{array}{l}\begin{array}{l}\text { Concentration of test } \\
\text { material } \\
(\mu \mathrm{g} / \text { plate })\end{array} \\
0^{\mathrm{a}}\end{array}$} & \multicolumn{5}{|c|}{ Average of revertant colonies (mean $\pm S \mathrm{~S}$ ) } \\
\hline & & & \multicolumn{3}{|c|}{ Base-pair substitution } & \multicolumn{2}{|c|}{ Frame shift } \\
\hline CSE1034 & S9 mix (-) & & $108 \pm 6$ & $24 \pm 2$ & $74 \pm 4$ & $26 \pm 3$ & $11 \pm 2$ \\
\hline & & 0.0015 & $108 \pm 5$ & $25 \pm 3$ & $73 \pm 5$ & $28 \pm 2$ & $11 \pm 2$ \\
\hline & & 0.005 & $107 \pm 5$ & $26 \pm 2$ & $74 \pm 3$ & $25 \pm 4$ & $12 \pm 1$ \\
\hline & & 0.016 & $107 \pm 6$ & $25 \pm 1$ & $76 \pm 2$ & $27 \pm 3$ & $10 \pm 3$ \\
\hline & & 0.05 & $106 \pm 7$ & $24 \pm 1$ & $75 \pm 3$ & $25 \pm 4$ & $11 \pm 2$ \\
\hline & & 0.16 & $105 \pm 5$ & $23 \pm 3$ & $74 \pm 3$ & $26 \pm 4$ & $12 \pm 1$ \\
\hline & $\mathrm{S} 9 \operatorname{mix}(+)$ & $0^{\mathrm{a}}$ & $118 \pm 6$ & $24 \pm 2$ & $88 \pm 5$ & $28 \pm 3$ & $14 \pm 2$ \\
\hline & & 0.0015 & $119 \pm 4$ & $25 \pm 2$ & $88 \pm 4$ & $27 \pm 4$ & $15 \pm 1$ \\
\hline & & 0.005 & $117 \pm 6$ & $26 \pm 2$ & $87 \pm 4$ & $27 \pm 3$ & $14 \pm 2$ \\
\hline & & 0.016 & $118 \pm 7$ & $24 \pm 3$ & $86 \pm 5$ & $29 \pm 2$ & $13 \pm 3$ \\
\hline & & 0.05 & $119 \pm 5$ & $25 \pm 2$ & $87 \pm 4$ & $27 \pm 3$ & $14 \pm 2$ \\
\hline & & 0.16 & $117 \pm 7$ & $23 \pm 3$ & $87 \pm 7$ & $26 \pm 4$ & $12 \pm 3$ \\
\hline \multirow[t]{6}{*}{+ Control } & S9 mix (-) & Compound & NaN3 & NaN3 & MMS & 2-NF & $9-A A$ \\
\hline & & Concentration ( $\mu \mathrm{g} /$ plate) & 1.5 & 1.5 & 2.5 & 2.5 & 25 \\
\hline & & Colony no. & $517 \pm 19$ & $345 \pm 13$ & $405 \pm 15$ & $322 \pm 8$ & $81 \pm 5$ \\
\hline & $\mathrm{S} 9 \operatorname{mix}(+)$ & Compound & 2-AAN & 2-AAN & 2-AAN & $\mathrm{BP}$ & $\mathrm{BP}$ \\
\hline & & Concentration ( $\mu \mathrm{g} /$ plate) & 10 & 10 & 10 & 20 & 20 \\
\hline & & Colony no. & $536 \pm 17$ & $406 \pm 12$ & $406 \pm 15$ & $332 \pm 16$ & $83 \pm 6$ \\
\hline $\begin{array}{l}\text { Historical } \\
\text { negative }^{b}\end{array}$ & & & $10-50$ & $60-220$ & $5-50$ & $1-25$ & $65-115$ \\
\hline
\end{tabular}

${ }^{a}$ Negative (solvent) control; the historical negative range was formed by reference literature; ${ }^{b}$ denotes historical negative obtained from literature.

The test material was mutagenic with either a two-fold increase over the spontaneous reversion rate (percent of control > $200 \%)$ or demonstration of a dose-response curve when dilutions are tested; and is non-mutagenic with either a less than two-fold increase over spontaneous reversion rate (percent of control < $200 \%$ ) or no dose response curve when dilutions are tested.

There were no significant differences in chromosomal aberration between CSE1034treated groups and the corresponding solvent group $(p>0.05)$. In contrast, the incidence of aberrant cells in each positive control group increased significantly when compared with each solvent group $(p<0.001)$. The incidence of cells having numeral aberrations (polyploid) did not increase in any group.

\section{DISCUSSION}

Chemicals that cause mutation can potentially damage germline leading to fertility problems and mutations in future generations. Mutations can be either point mutation, where only a single base is modified, or one or a relatively few bases are inserted or deleted, as large deletions or rearrangements of DNA. The Ames test has been recognized globally as an initial screening method to determine the mutagenic potential of new chemicals including clinical drugs because of its convenience and sensitivity [3]. However, this test cannot detect aberrations of chromosome induced by chemicals [8]. The studies carried out in bacteria, mammalian systems and cell cultures showed that some chemicals interacted with the genetic material and caused DNA damage [9]. Antibiotics, also known as antibacterials, are types of medications that destroy or slow down the growth of bacteria. $\beta$-lactam antibiotics are a broad class of antibiotics, that contains a $\beta$-lactam ring in their molecular structures. Antibiotic drugs are generally thought to have no mutagenicity. However, it has been reported that some antibacterial agents such as mitomycin $\mathrm{C}$ and tetracycline have mutagenic potential $[10,11]$. 
Table 2: Chromosome aberration results for CSE1034 in Chinese hamster lung (CHL) cells without S9 mix.

\begin{tabular}{|c|c|c|c|c|c|c|c|c|c|c|c|c|c|}
\hline \multirow[t]{2}{*}{ Compound } & \multirow[t]{2}{*}{ s9 } & \multirow[t]{2}{*}{$\begin{array}{c}\text { Time } \\
\text { (h) }\end{array}$} & \multirow[t]{2}{*}{$\begin{array}{c}\text { Dose } \\
(\mathrm{mg} / \mathrm{ml})\end{array}$} & \multirow[t]{2}{*}{$\begin{array}{l}\text { Scored } \\
\text { cell no. }\end{array}$} & \multirow[t]{2}{*}{$\begin{array}{l}\text { Polyploid } \\
\text { (\%) }\end{array}$} & \multirow[t]{2}{*}{ Judge } & \multicolumn{7}{|c|}{$\begin{array}{c}\text { Frequency of cells with chromosoma } \\
\text { aberration (\%) }\end{array}$} \\
\hline & & & & & & & $\operatorname{ctg}$ & $c t b$ & cte & $\begin{array}{c}c s \\
b\end{array}$ & cse & TAG & $T A$ \\
\hline Solvent & - & $24-0^{a}$ & 0 & 100 & 0 & - & 0 & 0 & 0 & 0 & 0 & 0 & 0 \\
\hline \multirow[t]{5}{*}{ CSE1034 } & - & $24-0^{a}$ & 0.34 & 100 & 0 & - & 1 & 0 & 0 & 0 & 0 & 1 & 0 \\
\hline & & $24-0$ & 0.69 & 100 & 1 & - & 0 & 0 & 0 & 0 & 0 & 1 & 0 \\
\hline & - & $24-0$ & 1.37 & 100 & 0 & - & 0 & 0 & 0 & 0 & 0 & 1 & 0 \\
\hline & - & $24-0$ & 2.75 & 100 & 0 & - & 1 & 1 & 0 & 0 & 0 & 1 & 1 \\
\hline & - & $24-0$ & 5.50 & 100 & 0 & - & 2 & 1 & 0 & 0 & 0 & 3 & 1 \\
\hline MMC & - & $24-0$ & 0.00005 & 100 & 0 & + & 36 & 14 & 65 & 0 & 8 & 87 & 78 \\
\hline Solvent & - & $48-0$ & 0 & 100 & 0 & - & 1 & 0 & 0 & 0 & 0 & 1 & 0 \\
\hline \multirow[t]{5}{*}{ CSE1034 } & - & $48-0$ & 0.34 & 100 & 0 & - & 0 & 0 & 0 & 0 & 0 & 0 & 0 \\
\hline & & $48-0$ & 0.69 & 100 & 0 & - & 3 & 0 & 0 & 0 & 0 & 3 & 0 \\
\hline & - & $48-0$ & 1.37 & 100 & 0 & - & 2 & 0 & 0 & 0 & 0 & 2 & 0 \\
\hline & - & $48-0$ & 2.75 & 100 & 1 & - & 1 & 0 & 0 & 0 & 0 & 1 & 0 \\
\hline & - & $48-0$ & 5.50 & 100 & 0 & - & 1 & 0 & 0 & 0 & 0 & 1 & 0 \\
\hline MMC & - & $48-0$ & 0.0001 & 100 & 0 & + & 27 & 9 & 48 & 0 & 2 & 51 & 44 \\
\hline Solvent & - & $6-18$ & 0 & 100 & 0 & - & 0 & 0 & 0 & 0 & 0 & 0 & 0 \\
\hline \multirow[t]{5}{*}{ CSE1034 } & - & $6-18$ & 0.34 & 100 & 0 & - & 0 & 0 & 0 & 0 & 0 & 0 & 0 \\
\hline & & $6-18$ & 0.69 & 100 & 0 & - & 1 & 1 & 1 & 0 & 0 & 3 & 2 \\
\hline & - & $6-18$ & 1.37 & 100 & 0 & - & 4 & 0 & 0 & 0 & 0 & 4 & 0 \\
\hline & - & $6-18$ & 2.75 & 100 & 1 & - & 3 & 0 & 0 & 0 & 0 & 3 & 0 \\
\hline & - & $6-18$ & 5.50 & 100 & 0 & - & 2 & 0 & 0 & 0 & 0 & 2 & 0 \\
\hline BP & - & $6-18$ & 0.02 & 100 & 0 & + & 2 & 0 & 2 & 0 & 0 & 4 & 2 \\
\hline Solvent & + & $6-18$ & 0 & 100 & 0 & - & 2 & 0 & 0 & 0 & 0 & 2 & 0 \\
\hline \multirow[t]{5}{*}{ CSE1034 } & + & $6-18$ & 0.34 & 100 & 0 & - & 0 & 0 & 0 & 0 & 0 & 0 & 0 \\
\hline & + & $6-18$ & 0.69 & 100 & 0 & - & 3 & 0 & 0 & 0 & 0 & 3 & 0 \\
\hline & + & $6-18$ & 1.37 & 100 & 0 & - & 0 & 0 & 0 & 0 & 0 & 0 & 0 \\
\hline & + & $6-18$ & 2.75 & 100 & 0 & - & 2 & 1 & 0 & 0 & 0 & 3 & 0 \\
\hline & + & $6-18$ & 5.50 & 100 & 0 & - & 2 & 2 & 0 & 0 & 0 & 4 & 0 \\
\hline BP & + & $6-18$ & 0.02 & 100 & 0 & - & 29 & 8 & 48 & 0 & 2 & 54 & 48 \\
\hline
\end{tabular}

a=Treatment time; Abbreviation: ctg; chromatid and chromosome gap, ctb chromatid break, cte; chromatid exchange, csb; chromosomal break, cse, chromosomal exchange, TAG; total cells which have chromosomal aberrants including ctg, TA; total cells which have chromosomal aberrants excluding ctg, MMC; mitomycin C, BP, benzopyrine

In the present investigation, the reverse mutation test with $S$. typhimurium and $E$. coli and the chromosomal aberration test with $\mathrm{CHL}$ cells were carried out in order to examine the mutagenicity of CSE1034 from the data obtained in this study, CSE1034 in non-mutagenic since there was either a less than two-fold increase over spontaneous reversion rate (percent of control
$<200 \%$ ) or no dose-response curve when dilutions were tested. There were no significant differences between results of CSE1034-treated groups in the absence and presence of the metabolic activation for both tests. Similarly, studies on the mutagenicity of cefodizime sodium on Salmonella typhimurium and Escherichia coli strains have observed that it has no mutagenic 
activity [8]. Cefotaxime and MT-141, which is one of cephamycins were also reported to be nonmutagenic $[12,13]$. In contrast, several $\beta$-lactam antibiotics such as penicillin $G$, ampicillin and carbenicillin have been reported to be mutagenic on the chromosomal aberration test with fibroblast cells [14]. However, when reverse mutation test was studied with S. typhimurium, penicillin $\mathrm{G}$ reported to be non-mutagenic [15].

\section{CONCLUSION}

The results obtained in the reverse mutation test indicate that CSE1034 is non-mutagenic.

\section{ACKNOWLEDGEMENT}

The authors are thankful to Venus Medicine Research Centre Werne, Germany, for providing assistance to carry out this study.

\section{REFERENCES}

1. Organization for Economic Cooperation and Development (OECD). Section 4 of the OECD guidelines for the testing of chemicals: bacterial reverse mutation test, guideline 471, adopted July 21st, 1997.

2. Gatehouse D, Haworth S, Cebula T, Gocke E, Kier L, Matsushima T, Melcion C, Nohmi T, Ohta S, Venitt S, Zeiger $E$. Report from the working group on bacterial mutation assays: international workshop on standardization of genotoxicity test procedures. Mutat Res 1994; 312: 217-233.

3. Mortelmans K, Zeiger E. The Ames Salmonella/microsome mutagenicity assay. Muta Res 2000; 455: 29-60.

4. International Conference on Harmonization. Genotoxicity: a standard battery for genotoxicity testing of pharmaceuticals. Topic S2B, Harmonised Tripartite Guideline. CPMP/ICH/174/95, 1997.

5. Ames BN, McCann J, Yamasaki E. Methods of detecting carcinogens and mutagens with the Salmonella/mammalian microsomal mutagenicity test. Mutat Res 1975; 31: 347-354.

6. Maron DM, Ames BN. Revised methods for the Salmonella mutagenicity test. Mutat Res 1983; 113: 173-215

7. Dusinska $M$, Kazimırova A, Barancokova $M$, Beno $M$, Smolkova B, Horska A, Raslova K, Wsolova $L$, Collins AR. Nutritional supplementation with antioxidants decreases chromosomal damage in humans. Mutagenesis 2003; 18: 371-376.

8. Ohuchida A, Yoshida R. Mutagenecity test of cefodizime sodium. J Tox Sci 1988; 13: 245-256.

9. Mirian CP. Chemical-induced DNA damage and human cancer risk. Nat Rev 2004; 4: 630-637.

10. Kada, T.; Ishidate, M. Environmental Mutagens Data Book No. 1. Scientists Inc., Tokyo; 1980; p 411.

11. Celik $A$, Eke D. The assessment of cytotoxicity and genotoxicity of tetracycline antibiotic in human blood lymphocytes using CBMN and SCE analysis. Int $\mathrm{J}$ Hum Genet 2011; 11: 23-29.

12. Mazza G, Albertini A, Galizzi A. A bacterial test in liquid culture for the detection of mutagenicity activity of antibacterial compounds: Studies with cephalosporins HR756. Farmaco Sci 1980; 35: 357-365.

13. Hirano F, Sindou $Y$, Mifune $Y$, Maeda $H$, Murata $S$. Mutagenicity test of MT-141. Jap J Antibiot 1984; 37: 918-927.

14. Byarugaba W, Rudiger HW, Koske-Westphal T, Wohler $W$, Passarge E. Toxicity of antibiotics cultured human skin fibroblast. Humangenetik 1975; 28: 273-267.

15. McCann J, Choi E, Yamasaki E, Ames BN. Detection of carcinogens as mutagens in the Salmonella/ microsome test: assay of 300 chemicals. Proc Natl Acad Sci (USA) 1975; 72: 5135-5139. 